\title{
THE PNEUMATIZATION OF THE TYMPANUM AND THE RELATIONSHIP TO THE FACIAL CANAL
}

By

Akira FUTAGAWA

From the Department of Oto-Rhino-Laryngology School of Medicine, Nagasaki University (Director: Prof. T. Goto)

In development of middle ear, the pneumatization of the mastoid cellulae is well known.

While the pneumatization of the tympanum is rarely discussed, tympanum itself has to pneumatize.

The author studied the relationship between the pneumatization of the temporal bone and thal of the tympanum, in vertical parallel section to pyramis in 50 cars of 50 cases.

Dimensions of the tympanum was measured by the planimeter, and compared with the rate of the radiographical pneumatization of the temporal bone.

Furthermore, the author observed the influence of the pneumatization of the tympanum to the facial canal wall.

The results are as follows:

1) High correlation between dimensions of the tympanum and pneumatization of the temporal bone was seen.

Namely, the better the pneumatization of the temporal bones, the wider their dimensions, however the degree of repression, did not show more narpowing.

2) The development of tympanal cellulae had u high correlation with the radiographical appearance of the temporal bone.

3) Themore developed the tympanum, the thinner was the facial canal wall.

This consequence is due to the absorbtion of bony tissue in pneumatization mechanism.

In 24 cases out of 41 , the facial canal wall defect was recognized in the portion of sinus tympani.

From the result of (3), the cause of the facial paresis in tympanoplastic procedure was discussed.

The author notes that when the tympanoplasty is employed in caseof a well developed pneumatization of the temporal bone extreme care must be taken.

\section{鼓室の含気化〔Pneumatisation〕，特に}

\section{顔面神経管との関倸について}

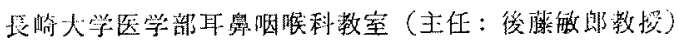

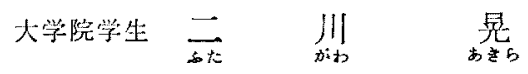

目次

I 㼋笔目的

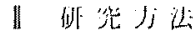

1) 研究材料

2) 㑡頭骨台気化 Pneumatisation (Pn.) の判定 規集
3) 棕本作裂沙

III砸究成䋘

1) 跂室の含父化について
a）鼓室の含気腔としての基本的な樈成
b) 故室腔の含気化について
c) 䩳室䗋窗の含気化について 


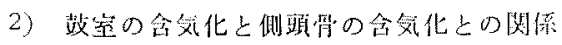

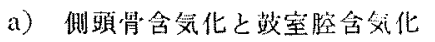

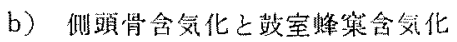

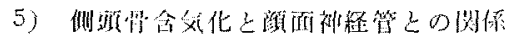

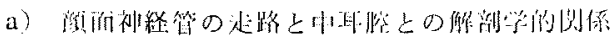

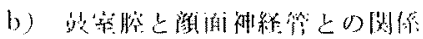

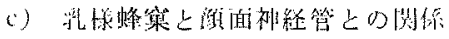

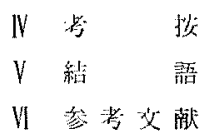

\section{I 研究目的}

中国脘の含気化 Pn. Кついては，Wittmack (1918)

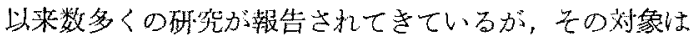

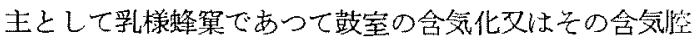
的な構成についての研究は極めて少ない。これは往来卧 休的に乳様蜂巢が叶耳经治療の目慓とされていたたるで あつて，又乳椂䗋集が組織学的，形態学的，レ線学的K も観察が容易なことにすその理由があった。しかし抗生 物質の普及によつて中耳炎の病態は，急速にしか心根本

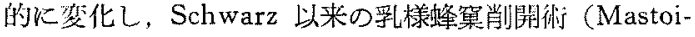
dektomie）によつて代表されていた中耳焱の手術法心 既に古典的なもの上是做されるよらになつた，更に鼓至 成形術 (Tympanoplastik) が中耳の主題日となるに至 つて, 孚様䗋勧は叶身炎手術の刘象上してはもし万第二

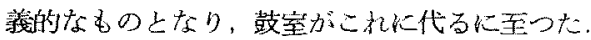

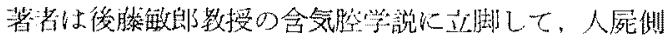

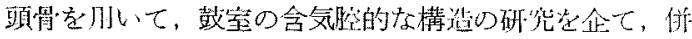

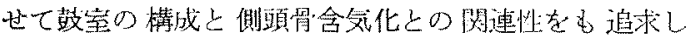

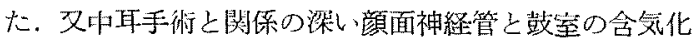
との関保学追求することとした。これは顔面神絽の横行

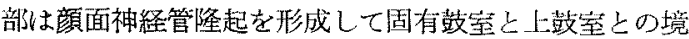

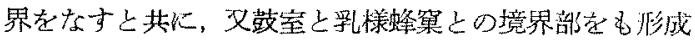

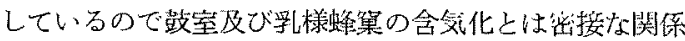

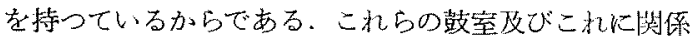
ある顔面神経管の形態学的研究によつて Tympanoplastik の参考に資せ九とするのがこの研究目的である。

\section{II 研究方法}

1) 研究秋料

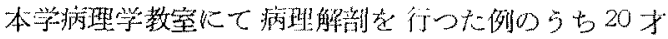
より 82 才までの 50 例の屍体より右側側頭骨の㨄出を仃

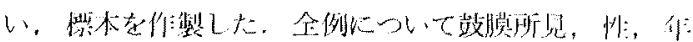

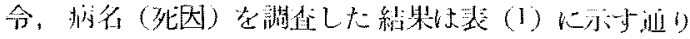

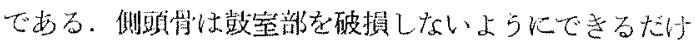

表 1

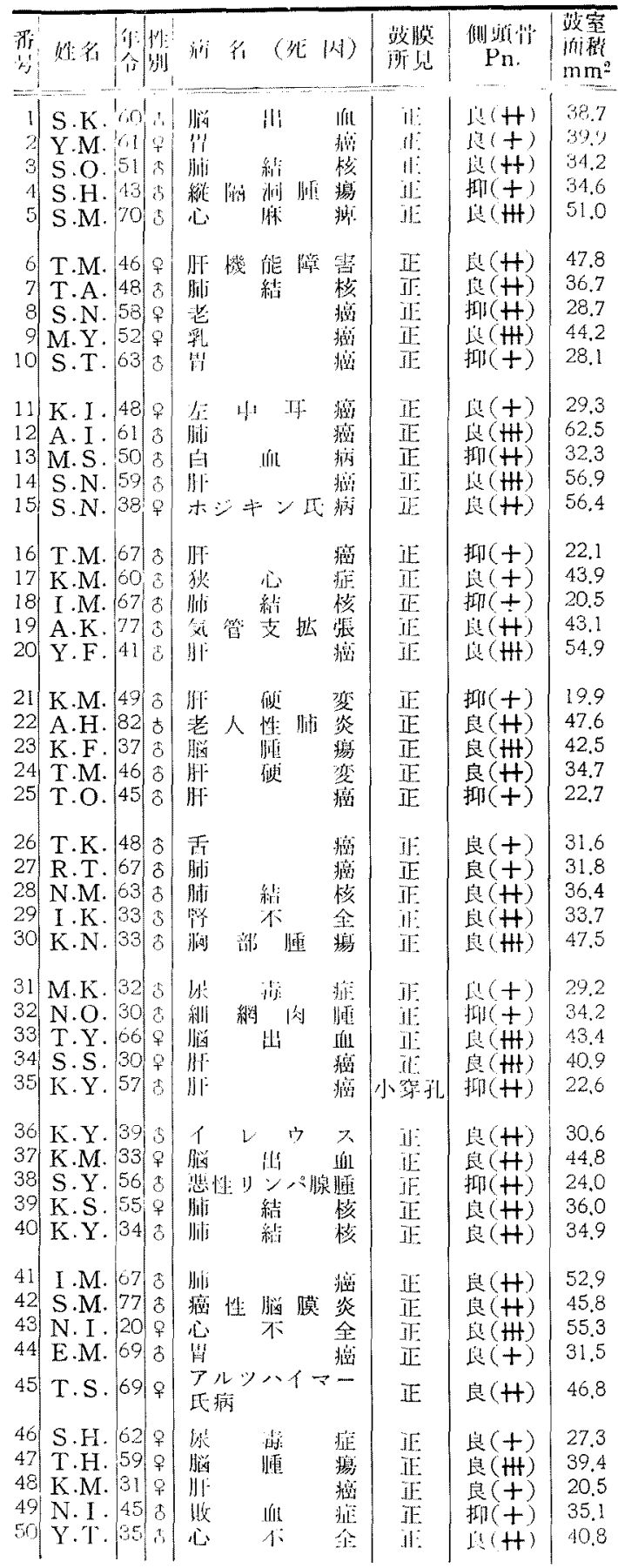


大きく取り出して軟暗組織を除去した徭，10\% Formalin 溶液で固定した。

2) 側頭骨·含支化の判定規準

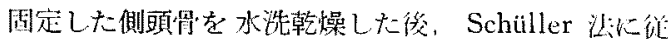

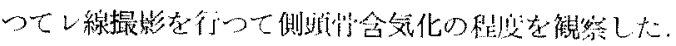

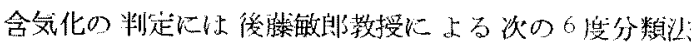

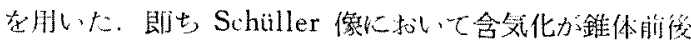

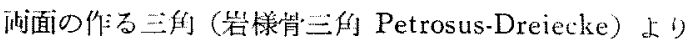

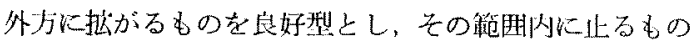
走抑制型とし，その各々を更に3度に分けた。往つて

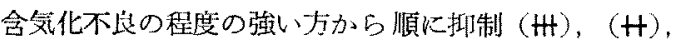

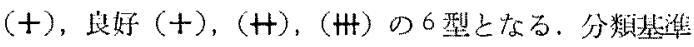
が良好と抑制の境界域にあつて決定困難なるのは，䗋穼 の大きさと隔壁の厚さとを参考にし，蜂笨の小さく圂壁

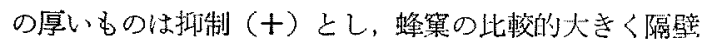
の薄いものは良好（十）として分類した。

\section{3) 標本作製法}

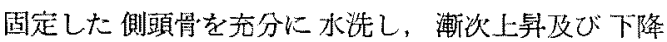
Alchohol 列を通して脱脂を行つた後，5\%硝酸 Formalin 溶液にて脱长し，ある程度脱辰したあ上，不要な 部分至除去して再び $3 \%$ 硝酸 Formalin 溶液にて充分 脱灰し，水洗脱水の過程を経て $2 \%$ Celloidin 溶液及 び 4\% Celloidin 溶液に各䄪 2 週間位, 8,\% Celloidin

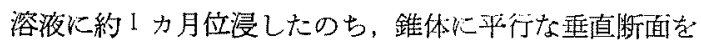

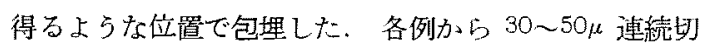
化を作製し，Hematoxylin-Eosin 重染色と，一部は結 众艟の染色として，ワンギーンン染色，マロリ一染色を 行つた。

\section{III 研究成 鈢}

1) 慗室の含気化について

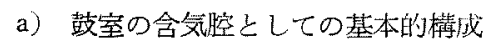

鼓室は上鼓室，中嫴室，下鼓室とに区別される、一般 に中敨室は固有鼓至又心䍩に鼓室と㭔ばれている。

上鼓室の含気化については，教筀の上田の詳組な発表

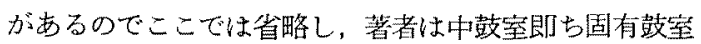
をお心とした莓成について研案することとした。

涉室は耳小骨とい5伝音機構を包含して，鼓膜を外壁 としているため，乳溙洞及び乳様浲窂とは孯質のものの よ5考えられているが含気腔として見るときは，含気 化の基本形式の狭意の洞腔部の一成分をなしている，含

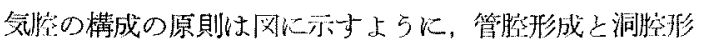

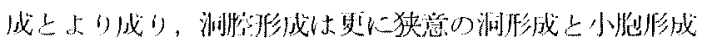

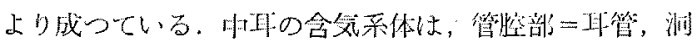

含叒腔の基本的情成

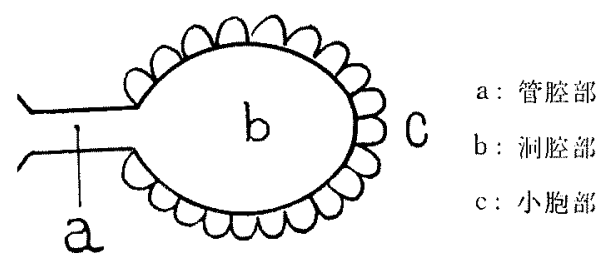

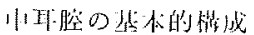

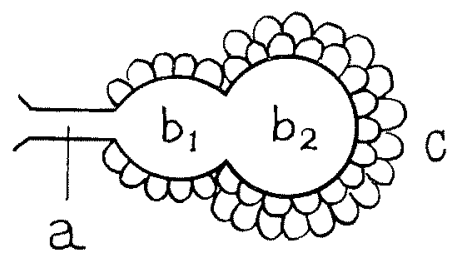

a : 乎管 =管腔部

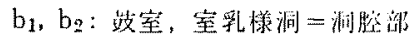

$\mathrm{c}$ ：乳様蜂案=小胞部

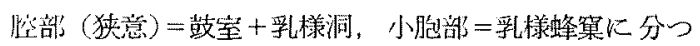
ことができる，小胞部は乳様蜂笨の名称の女と火經括的 に乎ばれていたが，これは妥当な名称でなく側頭骨蜂巢

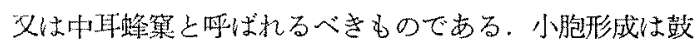
室及び乳様洞を中心として，その周辺に発㺚するもので ある、洞㓐部は中耳では，鼓室と乳様洞との二つの部位 から成立していることは含気膑としては特幑方る構造で ある、従つて中耳蜂笨群㤌耳管の未端部に一部存在寸る

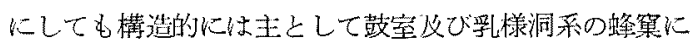

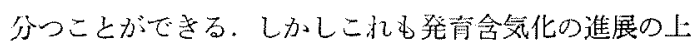

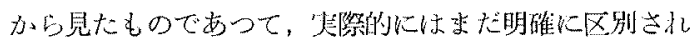

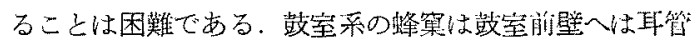

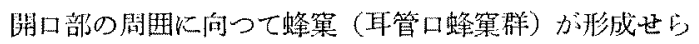

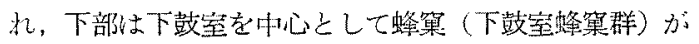
発肖し, 後壁では顔面神経管隆起の啳下部, 跂室洞の後

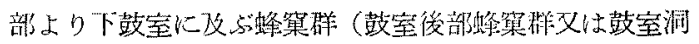

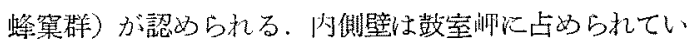

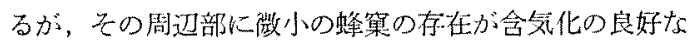
例に叔いてのみ認められている，上部外壁は顔面神絽管 陸起にて境されて上鼓室に移行している。こ机らの䗋策 群は，乳様蜂集や上鼓室の䗋集群に比軽するを，一般に

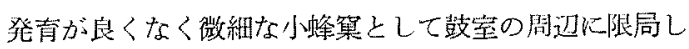
ている場合が多いが，例によつては都しく発育している

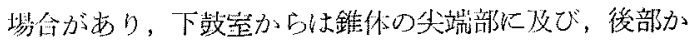

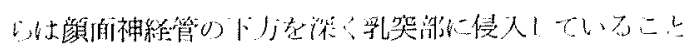
は経够们电和られていたことてむる。 
䍀床的に Tympanoplastik の際に鼓室悾が狭小で骨

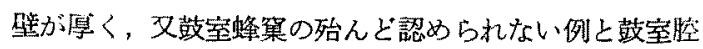
は広く鼓室盽窠の発育が良好で骨壁の薄い例に遭遇する ことる又しばしば経駼されるところである。このよらに 丵室の含気化にも著しい個体差の存在が推測さ机てお。

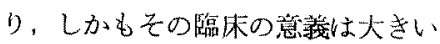

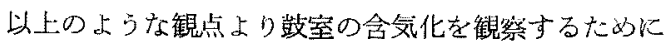
は、これを洞形成 (Höhlenbildung) と小胞形成 (Zellenbildung) とに分けて考光る必要がある.このために

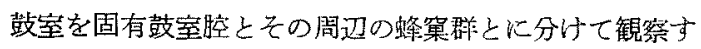
ることとした。

b) 鼓空腔の含気化について

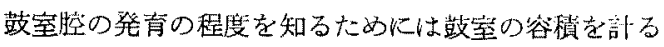
ことが理想的な万法であるが，それは椣めて困難なこと である、本邦に执いては，山口(1923) は固有鼓室腔の 大いさを鋳型唀本を作制して計測し，外山(1912)，森 川 (1925) は晒骨にてその上下堡，前後径等を計測し た。しかしこれらの法は著者の硎究目的に合致しない

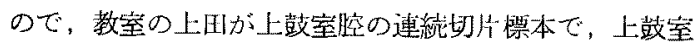
腔の含気化を観察した際に用いた方法を用いることと した．上田は上豉室腔の水平断面にて，Aditus に抽い て最も狭い部位の内外壁を結んだ面を基淮しして択ら び，その面皘を测定して上鼓室腔の大いさの缹準とし た.

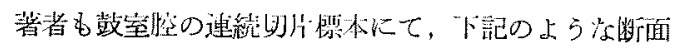

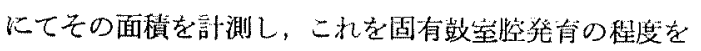
現わすものとした，车の断面の基準としては各橴本につ いて，錐体長軸に平行で水平面に垂真な断面で連続切片 を作つて行くと，写真（a）に示すよ5に先ず鼓室及 び耳小骨（Hammer）を含んだ面が認められる。更に前 方に進んで行くと豉室州が大きく出現して，その上K眀 円空窝が現れ Stapes が玩れる。更に前方に進んで行く

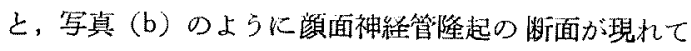
きて上鼓室と固有鼓室とを分つようになる。この部位の 断面を固有鼓公腔の面積測定部位とした。この部位の蜂 窠で，鼓室腔に開いた状態のものは固有鼓室腔とみな し，望梁で境されているものは鼓空蜂集として区別し，

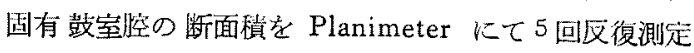
し、その平约值を求めた，その絬果情（1）に示すよ らに最大值 $62.5 \mathrm{~mm}^{2}$, 最小値 $19.9 \mathrm{~mm}^{2}$ で平均 $37.8 \mathrm{~mm}^{2}$ であり，個体差が非常に著明であることを示している，

この鼓室面積の分布の型を見るために，累稳度数百分 率を求わ，正規確率紙を用いて判定したところ，正規分
㭁をすることが確められた。そこで算術平均士標準偏 差の範囲内にあるものを鼓室発育の理想的なものと見 數し，その数值を求めたところ， $37.8 \pm 10.5 \mathrm{~mm}^{2}$ 即ち $48.3 \mathrm{~mm}^{2} \sim 27.3 \mathrm{~mm}^{2}$ の間に存在する 属するものと認められた， $48.3 \mathrm{~mm}^{2}$ 以上のもの8例は

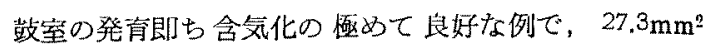
以下の 7 例は抑制例と双なすこととした。

この分布は，ばらつきの少ないもので，大部分の例が 音通程度の発青を保つていることを示している. 他の含 気腟，例えば乳様蜂穼や副鼻腔では発育度の個人差が谌 しく，或る場合には洞腔のみで，しがそれが極小な空 洞であるほど，極端に発青不良であつたり，或は反対に 発青が過度に良好な状態の6のが存在しているが，以上 の成績は鼓室ではこらした極端な発育差のないことを示 している、このことは鼓至が伝音機棈を納咸することか ら, 自然の合目的性がらかがわれる.この切片について 併せて豉空腔の上下径と前後佳を測定したが，上下径は 最大 $7.7 \mathrm{~mm}$ ，最小 $3.6 \mathrm{~mm}$ であり，平约 $5.0 \mathrm{~mm}$ であ つた，前後径は最大 $11.8 \mathrm{~mm}$ で最小 $4.2 \mathrm{~mm}$ で, 平均 $7.7 \mathrm{~mm}$ であつた。これらの值は面程とほぼ平行関係を 保つている.

c) 䟾室蜂集の含気化について

上記のように鼓室膑の蜂菓については，山口（1923） は金属鋳型により鼓堂蜂窠の発育状態力゙强い例 11 例,

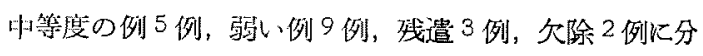

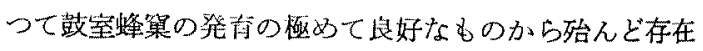
しないものまであるとしているがその分類の方法につい ては明らがされていない。

森川 (1942) は中国人 50 例 100 側の側頭愲について, 岩様部の鋸断を行つて豉空下部の骨蜂粕の值を計测し， 個人羑が著明であることを記載している。しかし蜂粱の 発育の基準についてい述べられていない。

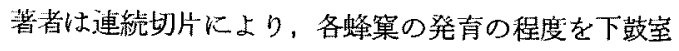
と鼓室後部の蜂巣について観察した。それれ教室では、 これらの部位の蜂笨の発生が箸明であるからである。蜂 窠発育の程度については, 蜂案の状能, 蜂窠聞の絬合織 及び浲菓の配列の状熊を觀祭して次の様に5度に分類し た.

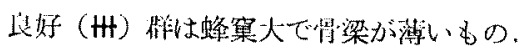

发好 (H) 群は蜂穼形成が少なくとも二層重つて存仕 与る程度の为の。

良好（十）群は蜂笨が小さく隔壁も厚いもの。

抑制（十）群は蜂窠は認められるが小さく筒梁間は結 
合蟣にて充されるるの.

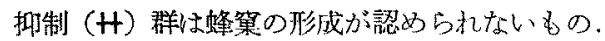

写真（c）は良好例を示し，写真 (d) は抑制例を去し ている，骨壁が厚く鼓室底部は平滑で蜂集の形成はあま

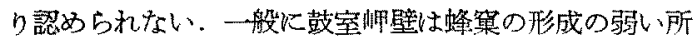
であるが，合気化の良い例では写真（e）の上うに小蜂 堡が見られている.しかし全般的に極めて轾微であるた かに観察は上記の 2 蜂垈群について行つた。

以上の基檴によつて観察例の鼓室蜂窗の発育度を分類 すると次の如くである。下鼓室䗋窠は47 例 (3耳:標本 の観察不良のため除外した）の5ち良好（H)8例(17 $\%)$ ，良好 (H) 13 例 (28\%)，良好 (十) 9 例 (19\%)， 抑制（十１1 例 (23\%)，抑制 (十) 6例 (13\%) であ つた，鼓空後部蜂策儿ついては47例の5ち，良好（世） 3 例 $(6 \%)$, 良好 (H) 10 例 (21\%), 良好 (十) 18 例 $(38 \%)$ ，抑制 (十) 9 例 $(19 \%)$ ，抑制 (H) 7 例 (15\%) であつた。

以上の成績より見れば下鼓室蜂窠良好例は30例，抑 制例は 17 例，鼓室後部蜂賲群は良好 31 例，抑制例心 16 例であるが，良好（十）以上の例が下靔室に多く， 後鼓室に少なく，蜂窖の発有の程度は下鼓室に强い上い らことが認められる。しかし両者の関係を同じ例的いい

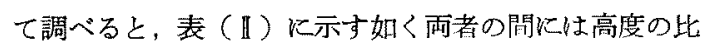
例関係の存在することが珰められる。

表 II 下鼓室䗋策と鼓室後壁䗋堡の相関関係 (組織学的所見による)

\begin{tabular}{|c|c|c|c|c|c|}
\hline 下壁の程度 & 抑 $(H)$ & 抑 $(t)$ & 良(十) & 良 (H) & 良(H) \\
\hline 良 （H） & & & & & $\cdots$ \\
\hline 良 (H) & & & & $\cdots$ & $\cdots \cdots$ \\
\hline 良 (t) & & $\cdots \cdots$ & $\cdots$ & $\cdots \cdots$ & \\
\hline 抑 $\quad(t)$ & & $\cdots$ & $\cdots$ & & \\
\hline 抑 (H) & $\cdots \cdots$ & $\cdots$ & & & \\
\hline
\end{tabular}

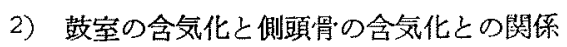

鼓室の含気化の程度と側頭骨全体の含気化との関係を 検討すると, 側頭骨の含気化の程度は前述の如き 6 度分 類法により，鼓室の含気化の程度は，鼓室そのものにつ いては㪗室の断面積值を用い，鼓室蜂柋の含弐化の程度 については，上記の鼓室蜂黛の形成状態を基潐にして分 類した。 a) 僛磌骨·含気化と固有鼓室腔含気化

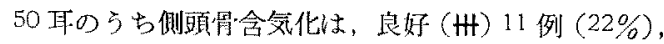

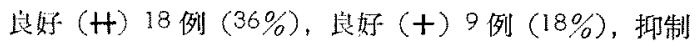
(t) 8 例 $(16 \%)$, 抑制 (H) 4 例 $(8 \%)$ で抑制 (H) の例はなかつた。

鼓空空の面積を求め側喕骨含気化との関係を表（圆）

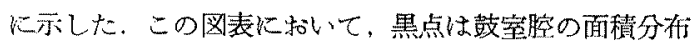
状態で，含気化の程度を示す各群份つて観察した。 印は側頭骨含気化各群に括ける各鼓室腔㸫面程值の平均 值を示した，統計的処理には次の其式に上り各群の平均

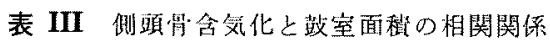

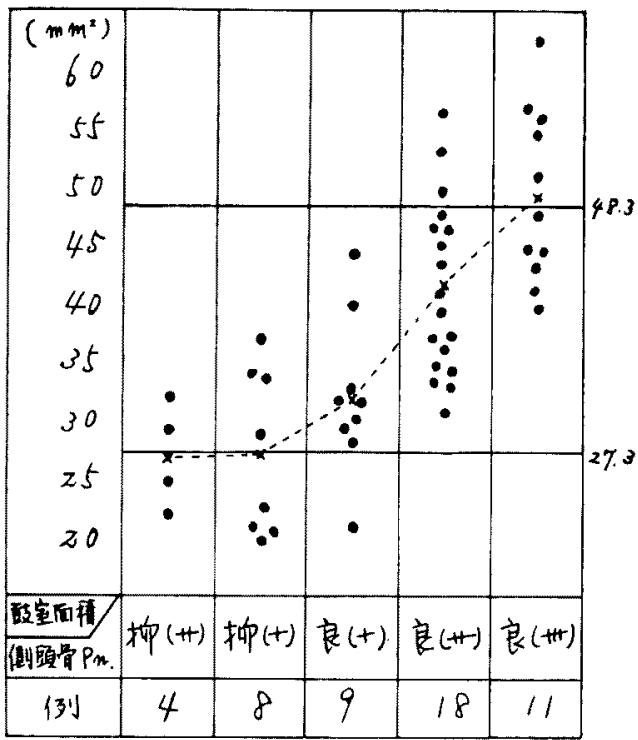

表 IV

\begin{tabular}{|c|c|c|c|c|}
\hline $\begin{array}{l}\text { 側頭骨. } \\
\text { Pn. }\end{array}$ & \multicolumn{2}{|c|}{$\begin{array}{c}\text { 攱室面榛 } \\
\mathrm{mm}^{2}\end{array}$} & 平均倠上譟差 & 例 \\
\hline 良 $(\mathrm{H})$ & $\begin{array}{l}\text { 最大 } \\
\text { 最小 }\end{array}$ & $\begin{array}{l}62.5 \\
39.4\end{array}$ & $49.0 \pm 2.3$ & 11 \\
\hline 良 $(H)$ & $\begin{array}{l}\text { 最大 } \\
\text { 最小 }\end{array}$ & $\begin{array}{l}56.4 \\
30.6\end{array}$ & $41.2 \pm 12$ & 18 \\
\hline 良(t) & $\begin{array}{l}\text { 最大 } \\
\text { 最小 }\end{array}$ & $\begin{array}{l}43.9 \\
20.5\end{array}$ & $31.8 \pm 2.1$ & 9 \\
\hline 抑 $(t)$ & $\begin{array}{l}\text { 最大 } \\
\text { 最小 }\end{array}$ & $\begin{array}{l}35.1 \\
19.9\end{array}$ & $27.2 \pm 2.2$ & 8 \\
\hline $\mathrm{m}(\mathrm{H})$ & $\begin{array}{l}\text { 最大 } \\
\text { 最小 }\end{array}$ & $\begin{array}{l}32.3 \\
22.6\end{array}$ & $26.9 \pm 1.7$ & 4 \\
\hline
\end{tabular}




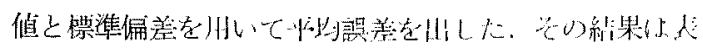
(N) に示寸如くである。

公式

$$
\text { 平均值 } \begin{aligned}
\mathrm{M} & =\mathrm{M}^{\prime}+\mathrm{Bw} \\
\mathrm{M}^{\prime} & =\text { 仮の平均值 } \\
\mathrm{B} & =\text { 級閆值 } \\
\mathrm{w} & =\text { 補正值 }=\frac{\Sigma \mathrm{f} d}{\mathrm{n}} \\
& \left\{\begin{array}{l}
\mathrm{f}=\text { 各級の度数 } \\
\mathrm{d}=\text { 級間偏差 } \\
\mathrm{n}=\text { 個数 }
\end{array}\right.
\end{aligned}
$$

標準偏差 $\sigma=\mathrm{B} \sqrt{\frac{\sum \mathrm{fd}^{2}}{\mathrm{n}}-\mathrm{w}^{2}}=\mathrm{B} \sqrt{\frac{\sum \mathrm{fd}^{2}}{\mathrm{n}}-\left(\frac{\sum \mathrm{fd}}{\mathrm{n}}\right)^{2}}$

$$
\text { 平均誤差 }=m=\frac{\sigma}{\sqrt{n}}
$$

以上の成績から側頭骨合気化と固有政室腔の大いさと の間には高度の正の相関関倸が認められた。このことは 教室の上四の上鼓室腔の研究成績之同様な関係を示して いる，即ち側頭骨の含気化良好の例で法，鼓室も大であ ることが明らかとなった。

前項で推計学的に豉室の含気化度が極めて良好である とされた8 例では，その側頭骨の含気化度忙，5例が良 好 (HI) で，3例が良好（H)であつた，迎に鼓室の含 気化が抑制されていた7 例の唄頭骨では，その含気化 は，1例は良好(十)，4 例は抑制(十)，2 例は抑制(H) に属しており，中等度以上に良好な例は認め得られなか つた。しかし側頭骨含気化の良好 (H)，(H)，(十)例 の各群の鼓室面積の平均值の間には大なる差が存在与る が，良好（十）之抑制（十）の同面積の間の差は小でか つて，抑制 (十) と抑制 (H) との同面積值の閒に结殆 んど差が薢められない，鼓室含気化を側頭骨含気化の各 群に分つて比較すると次のよらな関係が認められた。

良好 (H) 群の嗢室》良好 (H) 群の鼓室》良好 (十) 群の䓵室>抑制 (十) 群の鼓室二抑制 (H) 群の鼓室

推計学的に F 分布を用いて2つの標本平均の差を检 定すると，鼓室含気化は良好 (H)，良好 (H)，良好 （ナ）の間には，5\%の危険率で有意の差が認められた が，良好 (十)，抑制 (十)，抑制 $(H)$ の閣には有意の 差が認められなかつた。

この事実は倒頭骨の含気化が高度に抑制された例では 鼓室の大いさはそれに比例して小さくはなつていないこ とを現わしている。このことは文，踥室の持つ機能の上 から鋅室の含気化の抑制そのものにも限度のあることを 物語つている。

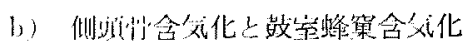

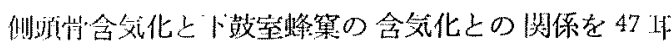

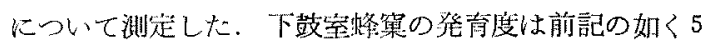
位に分つた。下鼓室䗋笨の発育度上 側頭骨含気化との 関係を表（V）に示した。この表に示す成績では雨者の 発寺废の閒には此例関係が存在することを示している。

表 V 側顓骨含気化と下站宝峰窠の 発育度との閣係

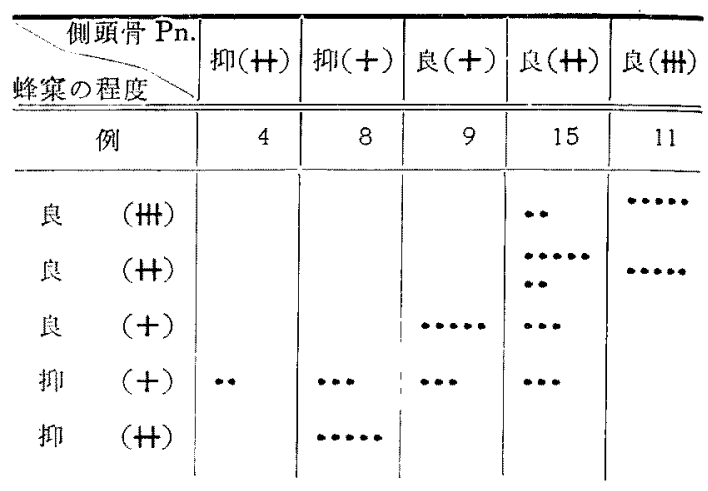

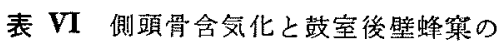
発育度上の関保

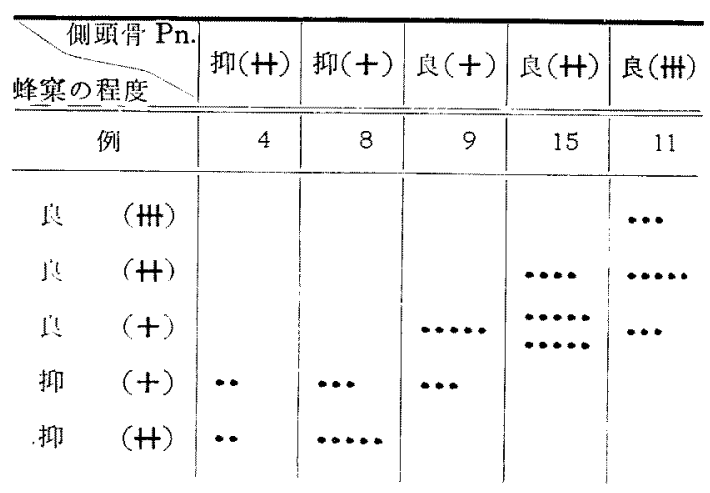

側頭骨含気化々鼓室後部䗋の含気化との関係は上記と 同様に 47 耳について 鼓室後部䗋筒の 発育度と側頭骨含 気化との関係を表 (VI) に示した。 その結果, 両者の間 には下鼓室蜂巢の場合と同様に，比例関原の存在するこ とが推定される. 即ち側頭骨含気化の良好なる例では， 鼓室蜂窝の発育恃極めて良好であり，側頭骨含気化の抑 制例では，鼓公蜂巢の発育が良くない。

鼓室䗋筒について山口は，乳椂蜂窝の良く発育した例 では良く発育した豉室蜂笨を有する例が多いと述べ，下 田は鼓室に和ける蜂笨の発育可良なる時は錐体尖端部及 び乳様部等に和ける䗋菒る又その発育は可良であり，反 


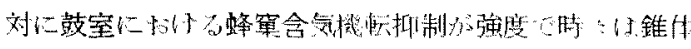

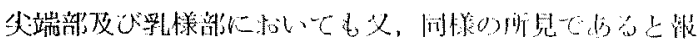
告している。

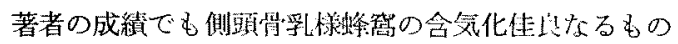

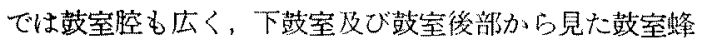

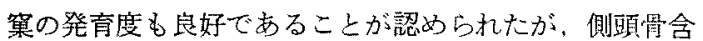
気化の発育抑制のある例では，鼓室点の人いさはをれに 此例した登育抑制の傾向を示さないことを明らかにし

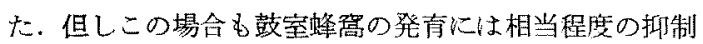
が示された結果が得られた。

3）側頭骨含気化と顔面神絽管との関係

a) 顔面神経管の走路々中耳腔との解部学的関俰

含気化の良好な例では顔面神絽管周囲の骨壁が薄くな ることは当然推測されることであるが，復雑な含気蜂笨 の形成との関係を観察することとした。

顔面神経の走路上側頭骨の合気䗋案との做剖学的閔係 を見ると，写真(f) のように内耳道底の戴战の上にあ る顔面神絽管入口を通つて, 顔面神縓筸に入り，顔面神

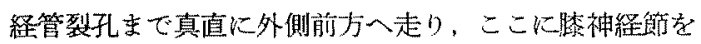
作り第一㹸部をなし，ここから殆んど直角をなして後外 側下方に曲り，水平半器官の骨包の後端下部で第二滕部 を作り，殆んど鉛直に下降して，茥乳突孔より頭蓋外底

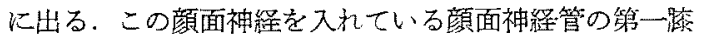

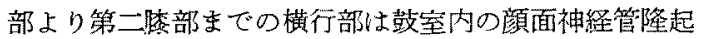
を形成し，上部及び内側部は緻密な半器官の骨包によつ て境されているが，外側部之下部は晊公腔内に隆起し， このためにその下面には鼓室洞 (Sinus tympani) 及び

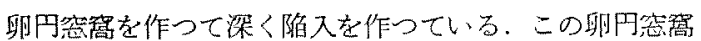
の上壁は骨壁が最も薄くなる部位でありこのことは鼓 室の含気腔発育の程度と深い関係を持つている，第二瞅 部より下行部の前壁は外耳道後壁の維密な骨梁で形成さ れているが，乙の後壁及び側壁は乳样蜂笨との関係が深 い部分である。このために顔面神絽管林横行部では靔空

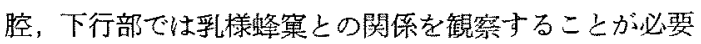
である。

b）攱室腔と顔面神経管との関係

豉室内の顔面神経管隆起の骨壁の状態を連続切片で観

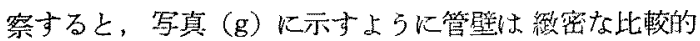
厚い骨質で形成されているが，例によつては骨壁は薄く 一部欠除し，結合織のみで形成されている例も認められ

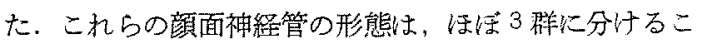
とがでさる。

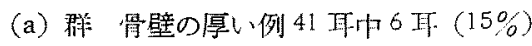

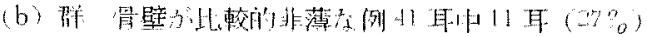

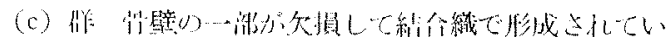
万例 41 191.12415 (58\%)

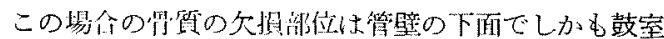
後部に拈いで認められている，久損例のうら更にとの程 度の強い例を抽出标ると 10 耳 $(24 \%)$ に当る。残りの 9 耳は組織標本がこの钼祭目的に適世なかつた。

鼓空腔の含気化度は削項で述べられたように鼓室面程 の值定用い，顔面神経管骨壁の組織学的所見との関係を 見ると，表（VII）に示す上5に，鼓室腙の発南の良贬な 例では管壁は，(c) 群に属している，推計学的に含気化

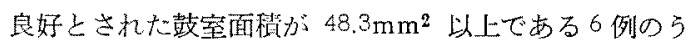
ち5 例が（c）群嘱して括り，鼓室面積が $27.3 \mathrm{~mm}^{2}$ 以 下の含気化の抑制されている6例では3例が（a）群に， 3 例が（b）群属している。

以上の事実より䩳室腔の発育の良い例では顔面神経管 隆起の下部の管質の欠損に注意する必要がある，豉室腙 の発育は側頭骨の含気化の発育と平行しているので，側

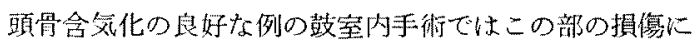

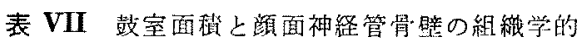
所見之の關係（權行部）

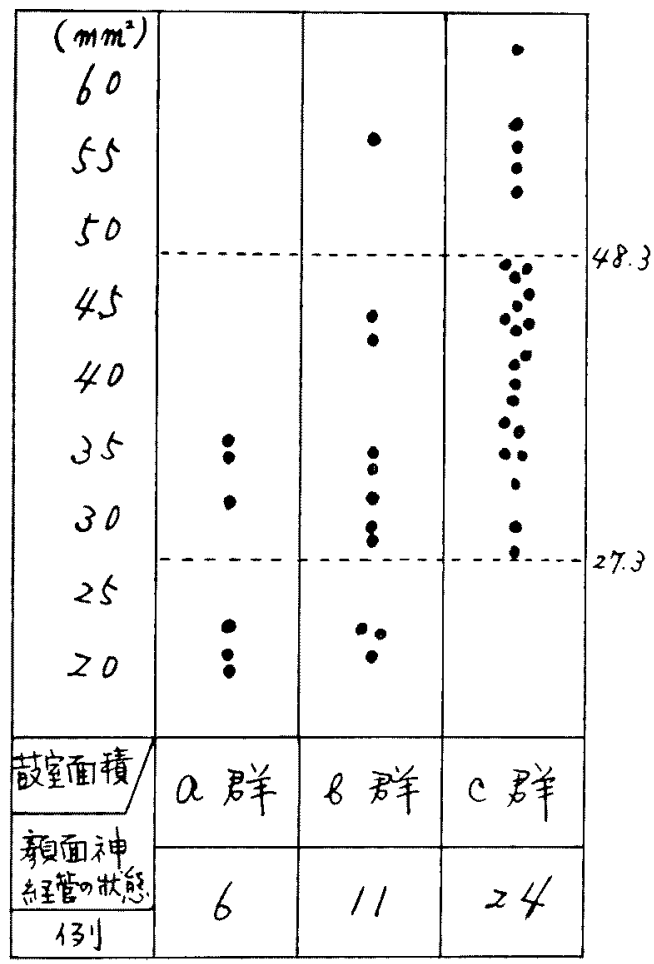




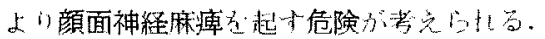

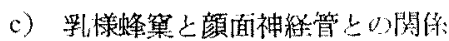

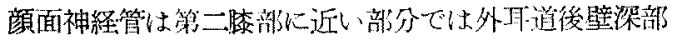

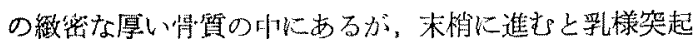
の蜂穼に包まれるようになり，蜂窠の発育の良い例では 蜂集壁は同時に神経管壁をなすに至る。下行部は長いこ とと，蜂筒の発育により走向が異ることために，連続切 片を作製してる全例を同一条件で観察することは困難で あるが，この蜂巢と神経管との関係を組織学的所見に上 りほば 3群に分類することができる。

(A) 群 厚い㴛密な骨壁にて囲まれている例41 耳中 7 年 $(17 \%)$

(B) 群 蛼䆚の発青良好のために部位によつて管壁 が薄くなつている例 41 耳中 12 耳 $(30 \%)$

(C) 群 䗋笨との問に骨壁を一部欠いている例 41 耳 22 F $(54 \%)$

写真 (h) は厚い骨壁にて囲虫れている。写真 (i) は (c) 群に属し含気腔と神経管とは一部が薄い結合織で隔 てられている.

表 VIII 僛頭骨含気化 (Pn.) と顔面神経管 骨壁の組馧学的所見との関係 (下行部)

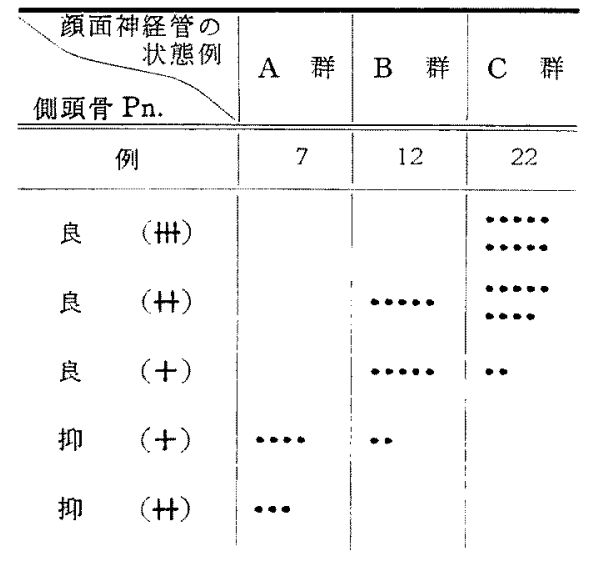

次に側頭骨の含気化の程度と顔面神経管壁の構造との 䦔係をみると，表（VIII）に示すよらに側䫄骨含気化の良 好例では，骨壁の一部欠除するむのが大部分であり，逆 に側頭骨含気化抑制例では，全て (A) 群に属して括り， 乳様䗋䆵の含気化は，顔面神経管周囲骨壁をも吸収して 行くもの之見故される。

\section{IV 考按}

豉室腔の形態学的な研究については，外山は14才八

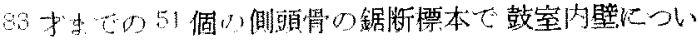

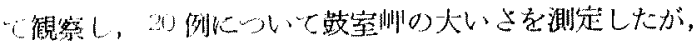

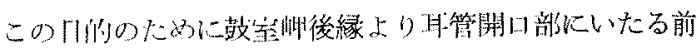

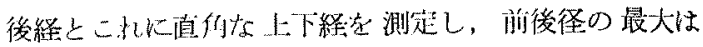
$9.0 \mathrm{~mm}$ ，毁小心 $6.5 \mathrm{~mm}$ で平均 $7.8 \mathrm{~mm}$ とし, 上下佳は 最大 $7.0 \mathrm{~mm}$ ，最小 $4.5 \mathrm{~mm}$ で平均 $5.8 \mathrm{~mm}$ として，個人 差の大であることを述べている.

做室䗋荣については，鼓至下底の鼓室哪の前下緑にそ らて存在するが，これが後下縁の後部の方にむ見られた ものが 4 例，又2例に执、ては後部にのみ存在したと述 べている，山口は成人 41 個, 小児 10 個, 胎胃 5 個の側 頭学の含気膑の金属鋳型を作り，固有鼓室の大いさを 測定し，平均值は長径は成人では $11.71 \mathrm{~mm}$ ，小贸では $10.6 \mathrm{~mm}$ ，胎先では $10.07 \mathrm{~mm}$ ，高径は成人では 10.81 $\mathrm{mm}$ ，小照では $9.72 \mathrm{~mm}$ ，胎界では $8.3 \mathrm{~mm}$ とした，又 鼓室蜂巢については，成人では強 11 例 $(36.6 \%)$ ，中 5 例 $(16.6 \%)$, 搦 9 例 $(30.0 \%)$, 残遗 3 例 $(10 \%)$, 欠 2 例 $(6.6 \%)$ であるとし，鼓室の下壁が強く発育した頸 静脈球のために上方に臣迫せられた場合には，鼓室蜂集 の発育が極めて抑制されるか或は全然存在しない例が3 例に認められたとして，郚床上與味ある事実とした．森 川は中国人の成人側䫒骨 50 例について豉室部の計測を 行つたが，政空下壁に和ける路窝の発育状態を調查して 鼓室下壁の骨䗋案について調べた，鼓室下壁には蜂窘の 発青良好なもの 41 例, 発育不良なもの36例, 蜂窩の欠 除し骨梁の隆起のみを見るもの6例，蜂粱及び骨隆起の 久侩したもの17 例, 又骬蜂笨の発育良好例のみについ て調查し，鼓室佃の前下方に陷入した䗋㑿の発育のみら れたものは12 例であるとし，鼓室下壁は蜂案の存在は 不定であるが，多くの場合は多少の骨蜂简の存在を見 て、窲粒大ないし米粒大に発育しその形は不整形をなす とした，以上のように鼓宝の形態についての研究は少な いが，いずれる計測の面からの研究であつて個人差が強 いことは認められている。

後藤教授は中耳及び副畧腔の含気腔は，その種類と発 育の程度により洞形成を主体として発育しているか，小 胞形成を主体として発育しているか, 又唡者の混在に よるものかと述べている。これらの含気腔の形態は異っ ているが本質的には两成分の形成をなし5る可能性を有 している.乳様䗋简では（小胞形成+洞形成）の形式で 発育しているが小胞形成が特に莑明で乳様突起の周边を 含気化していく壷心性の発育上共に乳様洞 (Antrum mastoidea) K向つて発育していく求心性の発育もあっ 
て元来腔洞である乳様洞がそのために殆んど小胞化され る場合もしばしば認められるので乳様洞の大いさと全体

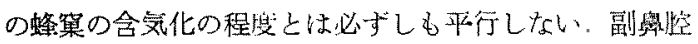
飞执いては上顎洞，蝶形骨洞，前頭洞は洞形成の極めて 強い含気腔であり，終生圭の発育が行なわれているが， 小胞形成の㑯向は弱い，管骨蜂笨は小胞形成がやや強い 含気腔と見做されている。

豉室比沶いて子基本的な形式である洞形成と小胞形成 とに分けて観察することが妥当であると思われる。年の 洞腔部としては鼓室腔が相当し，小泡部としては鼓室蜂 笨がこれに相当する。洞腔部の発育の程度についてはす でに述べたように，鼓室の前方よりの垂直断面で顔面神 経管の断面を含む鼓室断面を測定基潐とし，この断面の 面積によつてその程度を表らわすこととした。この表示 法は鼓室の容積を計ることのようにその真の容積を表ら わすことはできないが，含気化の程度を知ることはでき る. 本法に上る面積の測定值は，最大 $62.5 \mathrm{~mm}^{2}$ ，最小 $19.9 \mathrm{~mm}^{2}$ でその差が極めて大である。即ち鼓室の大い さが個体によつて異なることを示しているが，交献に示 された前項の報告值よりも遥かに大さい，

散室蜂窠については主に組織学的に蜂简の形態を観察 し分類することにした．本法に上ると蜂黛の発青の観察 そのものは最も理想的に行われることができる. しかし

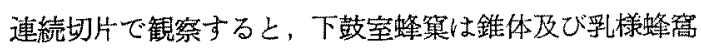
と融合して行くので，その境界を決めることは，蜂窠の 発育の良好なるものでは困難な例もあつた。しかし鼓室 腔内には求心的な蜂䆞形成の傾向も見られた。即ら 4 例 に批いては鼓室岬の下縁にも蜂巢の形成が認められた。 このような䗋笨は鼓室の後壁に連つている。しかし乳様

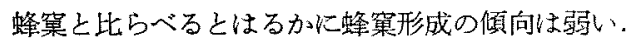

この鼓室の洞形成上蜂简形成との関倸は上記に示した 如く洞部の発育の良い例即方鼓室腔の大なる例において は，鼓室蜂笨の発育が㩆著である，近代鼓室の小なるも のは蜂窠の発育も抑制されている。これらの鼓室の含気 化の良好或は，抑制は側頭骨の含気化と非常に高度の相 関関係が認めら机た。

下田（1932）忙成人屋体 30 体 56 耳の組織解剖学的研 究において，豉室の発䏍良好なる例では孚様部及び錐 倈尖端部の蜂简子発育良好であり，反対に鼓室における 含気機転抑制が強度でその発育を欠除した例では乳様部

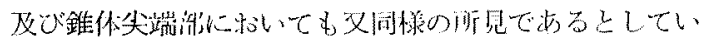
b.

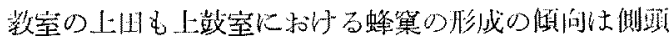

岗含武化に関連性を有するとした，後滕教授は中耳の含 父化の版制ということは蜂煲のみの発育抑制ではなく側

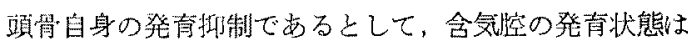
搆成骨単位にみるべきものであるとしているが，鼓室の 発育子側頭骨の発育状態により支配されるむのであるこ とが認められた。

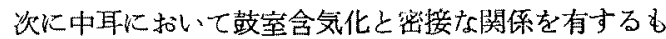
のは顔面神経管の状態である，鼓室内に括ける顔面神経 管隆起は，墥室内壁に沶いて卵円空の上万隆起し，外 半器官隆起と共厄上鼓室との境界を形成している。この 隆起はその外下壁が極めて菲薄で往々骨質の欠損をきた し，わずか炕結合織及び战莫により哣室腔と分界されて いるために鼓室の㫊的機枟は，容易汇顔面神経汇影響を 与えその手術操作は又その損傷を起し易いるのと思われ る.

Joseph（1900）及び Rüdinger（1873）は骨欠損を先

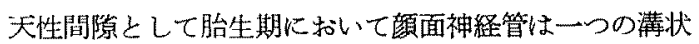
をなして化骨形成と共汇漸次骨質が発育して遂に骨管を 構成するのであるが，時々骨の欠損を遗残することがあ るとしている. Schwalbe (1887) は新生見及び幼年期 に和いては骷損が少なく成人に多く存在することから この現象忹骨の昅收作用に上るわのとしている. Henle (1873) は成人には常に骨欠損の存在を認めその原因は Schwalbe の説炕賛成している. 菊池, 吉永は60例中 21 例 $(35 \%)$ 亿間隚の存在を証明している. 森川は 100 例中 15 例に間隚の存在を見たとしている.

著者の観察では 41 例中厚い骨壁のもの6例 $(14.6 \%)$ ， 薄い骨壁のもの 11 例 (27\%), 骨壁の一部欠損の見られ たもの 24 例 $(58 \%)$ であつて，この5ち骨欠損の広い ものは10例 $(24.4 \%)$ であつた。こ礼らの骨壁の欠損 例は鼓室の含気化の良好な例に多く，含気化の抑制例で は厚い骨壁の例が多いこと又欠損の起つている部位が䚳

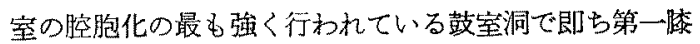
部の下面に存在していることから辢室内の含気化の機序 に上る骨吸収のために起るものと推定される。この推定 は Schwalbe の説と一致する。

最近 Tympanoplastik の普及によつて 慢性中耳炎の 治㙩の中心は豉室膑の処理にしばられて来だ。 Tympanoplastik の場合の顔面神経麻瘦の発生率はいか程であ るかといら文献は我が国では今だ見られない，海外の最 近O文辣以 41- Bukhman (Russisch) (1961) it 233

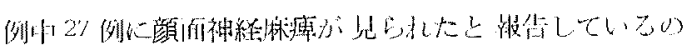
みである、我加教公では最近 4 例が跟告されている。 
れは失敗例であるために報告することが少ないためと思

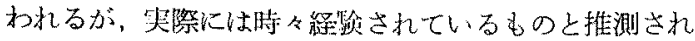
る.

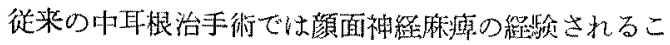
上は多くは直接の損傷によるものでその発症例も極めて 少ないが，Tympanoplastikでは，従来の中耳手術より あ起り易い条件を持つていると思れる，一般に耳性顔面 神経麻疩の起り方としては次の原因が考えられる。

(1) 直接損傷

(2) 間接預傷 a) 感染

b) 充近，出，侐浮朠

Tympanoplastik に执いて顔面神経の椇甥を起す部位 として考えられる可能性は次の上うである.

1）顔面神絟管の欠損部の存在

2) Chorda tympani 管

3) N. stapedius 管

顔面神絟管の組織標本の観察によつて顔面神経の第一

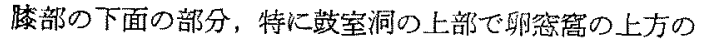
部分では骨壁が極めて薄いか又は欠損例が多いことは既 に述べたようである．鼓室の含気化との咸係ではその良 好なもの即ち側頭骨の含镉化の良好なものではこの上う な学壁が非薄又は欠損例が多いことが明らかとなつた。 従つてこのような例では，搵爬の際に直接の損傷を受け 易いこ上は当然考えられる，損稘しなくても，感染又は 鼓室内の出近に上る影響も受け易い。

Chorda tympani は標本で見ると骨管が絸くて比較的 長い故に，たとえ引き拔かれた場合にもこの緗い管を通 どての感染は考光られにくい。

N. stapedius は M. stapedius の損傷に上つて起り 得るが,この部位の損傷は骨壁の薄い:部分である関係も あつて，顔面神絟損傷又はその管の内感染又は反応性の 出血，浮䐸等を起す可能性が考えられる。

このように Tympanoplastik の祭には顔面神経际瘦 の合阙の可能性は従来の中耳手術に比べて大であるから 側頭骨の含気化の艮好な例では乎術の際に，解剖学的立 場から注意が必要であることが云方る，顔面神経下行部 では乳様蜂笨の含気化機序のために非薄となり 41 例中

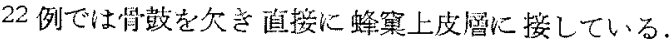
これに反して側頭骨含気化の抑制例では厚い深梁で因ま れていた。

\section{$\mathbf{V}$ 結 語}

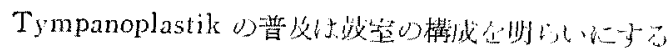

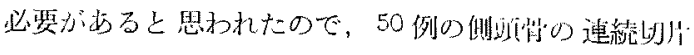

棒本につき，嚾室の含気崆的な構成を観察し，側頭骨の

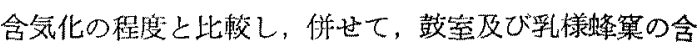
気化之密接なる闒係があると思れる顏面神経管の組織学 的研究を行つて, 次の結果が得られた。

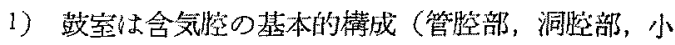
片部）のらち乳梯洞 (Antrum mastoideum) と共に, 洞控成分をなし，峷室峰罙はその小胞成分をなしてい 万.

2）固有站室腔の含気化の程度の示標としては，その 断面積を測定した。最大值 $62.5 \mathrm{~mm}^{2}$, 最小檤 $19.9 \mathrm{~mm}^{2}$ で算術平均は $37.8 \mathrm{~mm}^{2}$ で標準偏美は $10.5 \mathrm{~mm}^{2}$ であつ た.

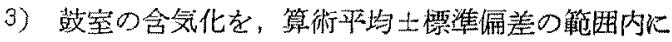
あるもの理想的な例とした場合に 50 例中 35 例はこの

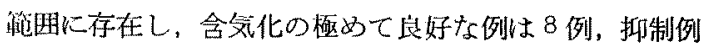
は7例であった。

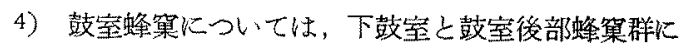
ふいて観察した，下鼓室蜂窠では，発育良好なるものは 47 例中 30 例，抑制例は 17 例であつ大゙. 鼓室後部蜂笨 では良好例31 例，抑制例 16 例であった。 全般的に下鼓 室の蜂菒形成が著明であるが，両部蜂窠の含気化の程度 は平行した。

5）政室の発育は側頭骨の含気化の程度により支配さ れ，両都には高度の相関関係が認められたが，側頭骨含 気化が強く抑制された場合ではこの関倸は成立せず，鼓 室には必ずしも甚しい含気化抑制は㒛められなからた。

6) 鼓空䗋算の含気化も側頭骬含気化と比例関係が認 めら机た。

7）顔面神絽管之鼓室及び孚㥭䗋窝の含気化度之の成 俰では，41 例中 24 例に拉いて鼓室後部即ち鼓室洞の部 位に执いて骨壁を一部欠いている例の存在することが認 められた。

8）願面神経の下行部に打いても41 例中 22 耳に执い て骨壁が一部欠除し，結合織汇よつて䗋巢に接している ことを認めた。

9)これらの顔面神経管婴壁の欠提认鼓室及び乳样烽 笨の含気化の良好なることと関係を持つもので，含気化 機序による骨吸収によるものであるとし，Tympanoplastik に执いて注意を要するものとした。

\section{文献}

1) Wittmaack: Uber die normale und die pathologische Pneumatisation des Schlafenbein. Gustav Fischer, Jena, 1918. 2) Henle: Handuch der 
写真（a）上鼓室及び耳小骨を含んだ面

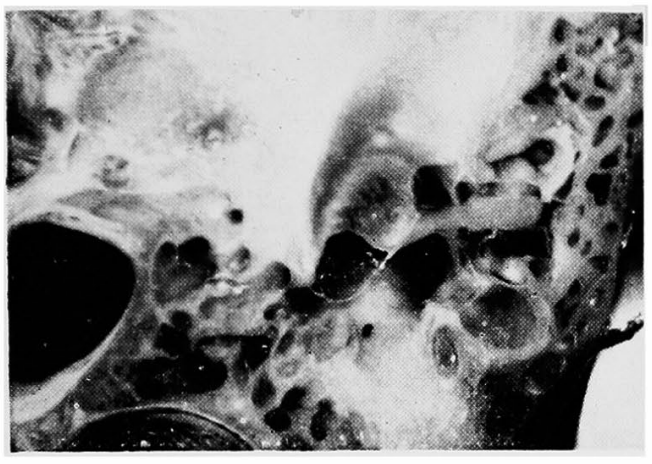

写真（c）下敨室蜂穼の良好例

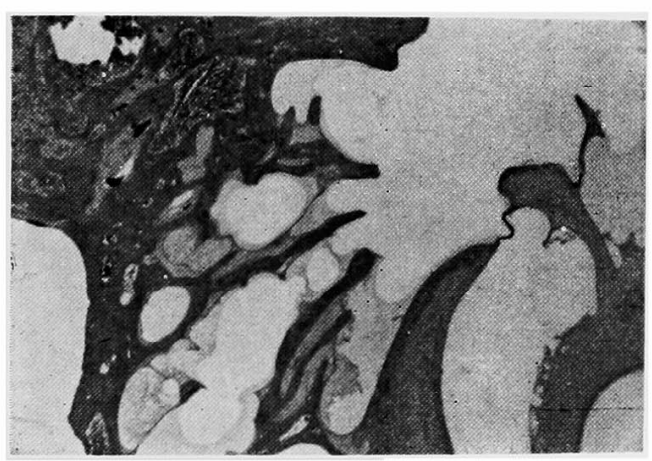

写真（d）下㪗室爻び鼓室後部䗋策の抑制例

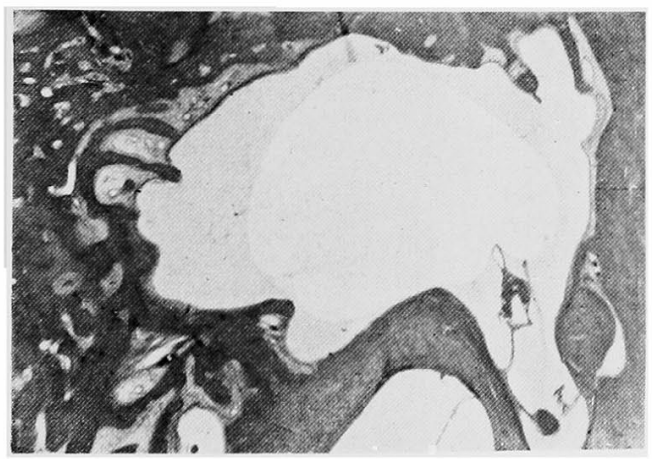

写真（b）顔面神経管隆起の断面が現れてき て上啜室と固有故室とを分つ面 （吱室面積测定基準面）

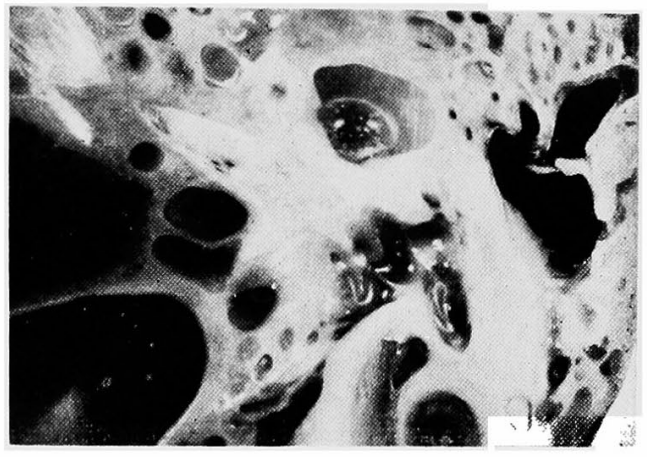

写真（c）鼓室後部蜂策の良好例

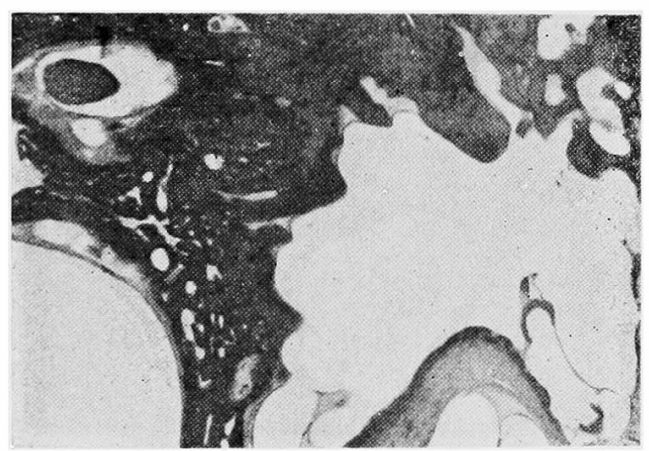

写真（e）鼓室岬壁の蜂军形成

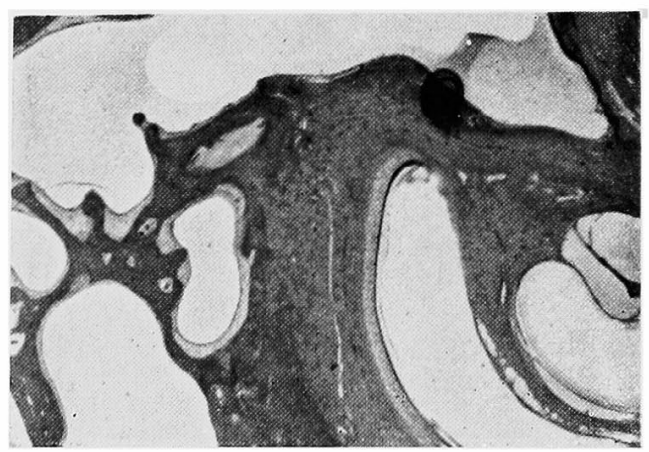




\section{二 川論文附図（II）}

写真 (f) 顏面神経の走路（镍行部，下行部）

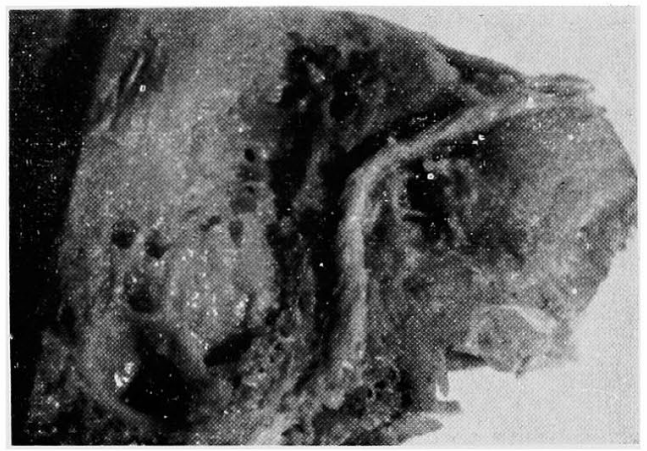

罙真（g）顔面神経管骨壁の菲薄な例（横行部）

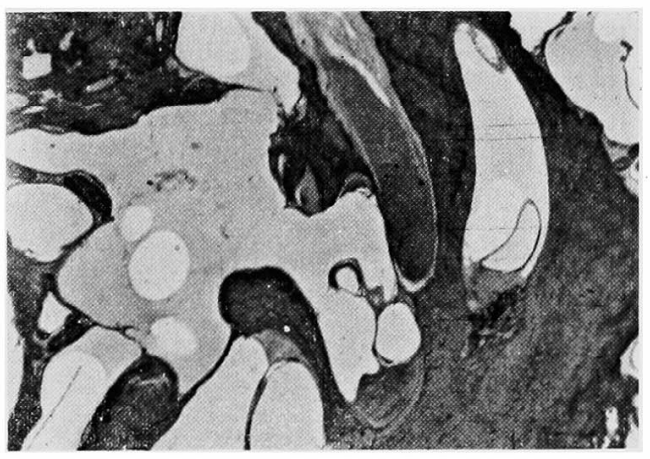

写真（h）顔面神経管が厚い骨壁にて囲まれ ている例（下行部）

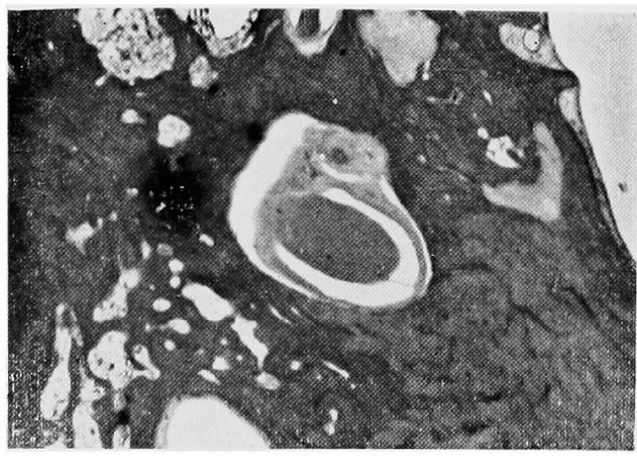

写貝（g）顔面神释管骨壁の比校的厚い例（横行部）

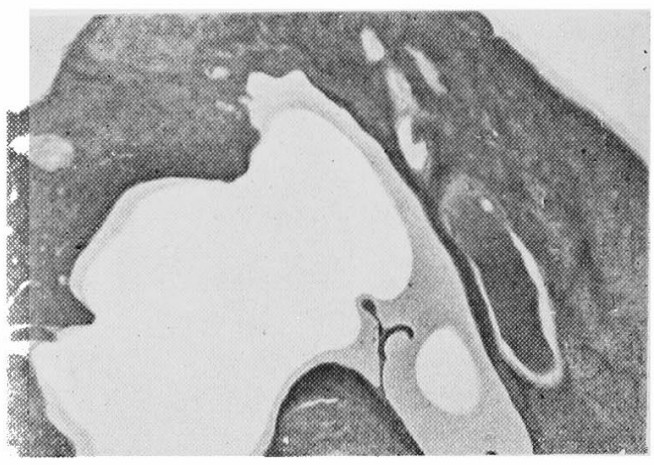

写真（g）顔面神経管骨壁の一部欠損例（横行部）

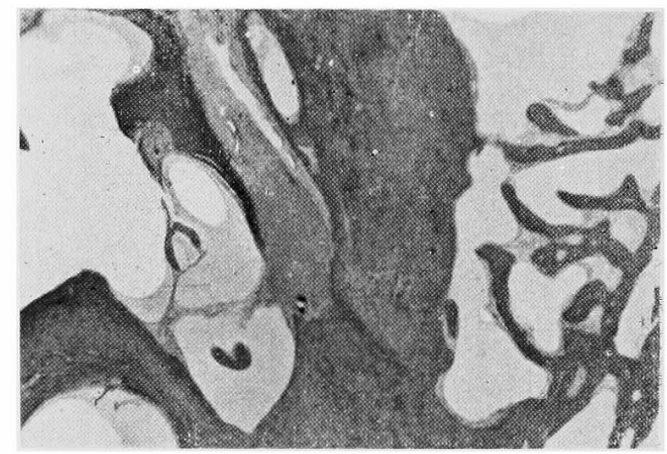

写真 (i) 顔面神経管が含気腔にて国まれ一部が薄 い結合織にて隔てられている例（下行部）

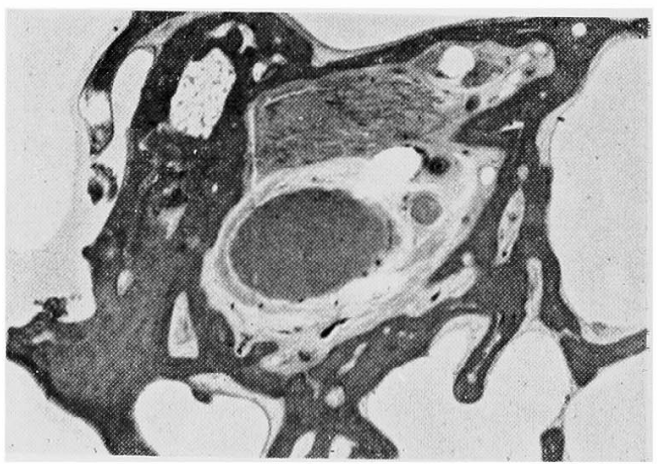


systematischen Anatomie. Bd. 2, 1873

3) Joseph: Osteologische Beitraege über das Schlagenbein und den ihn enthaltenen Gehorsapprat. Osterreich Otolog. Gesellschaft 1900.

4) Ruedinger: Über den Canalis facialis in seiner Beziechung zum siebenten Gehirnnerven beim Erwachseen. M.F.O.Bd. 7, 1873. 5) Schwalbe: Anatomie der Sinnesorgan. 1887.

6) L.A. Bukhman: Spätergebnisse der Tympanoplastik. Vesten. Oto-rhino-laryng. Mosk. 23, 17, 1961. 7) L.Bernsteit: A surgical approach to the tympanic portion of the facial nerve with methods of preoperative investigation. Ann. Oto. Rhino. Laryng. 70, 194, 1961. $\quad$ 8) H.E. McFuge: The surgical treatment of facial paralysis and traumatic conductive deafness in fractures of the temporal bone. Ann. Oto. Rhino. Laryng. 68, 855, 1959.99$)$ 後滕敏郎: Pneumatisation の成立とその噪床，日耳:

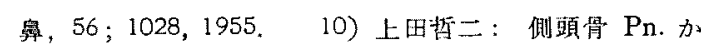
ら見た上豉室の発育と耳小骨連鎖との関係につい，日耳: 鮙, 66,10,1965. 11) 外山理市：本邦人の䟾室内 壁について，耳鼠監，8；1，1911。12）11口襱：金

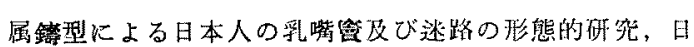

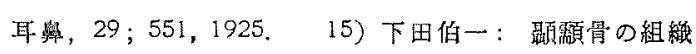
解剖学的研猋，日耳鼠，58；209，1952。114) 菻川政

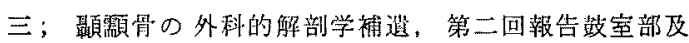
び岩様部の局所解剖学, 耳奥臨, 20; 57, 1925.

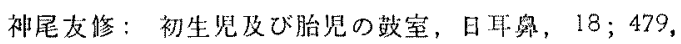
1910.16）十倉頪介：「アントルム」, 敋室上窩及び

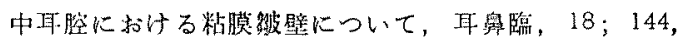
1924, 17) 小林泰：中耳 Pneumatisation の生後の

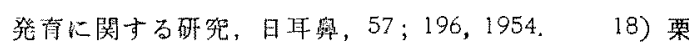

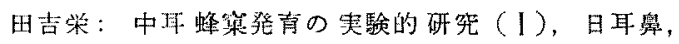

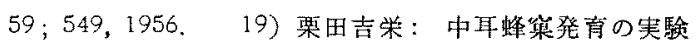

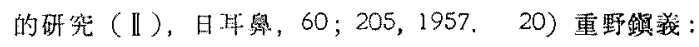
慢性中年炎と Pneumatisations hemmung の関係につ

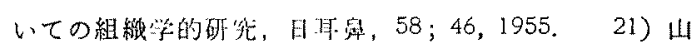

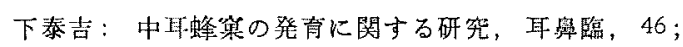
439，1955. 22) 土田武正：側頭骨含気腔について,

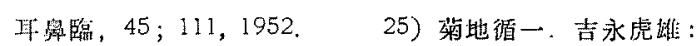

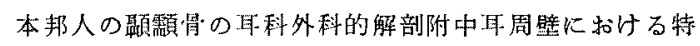

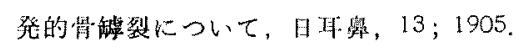

（原棏到着=昭和 40.2.27日） 